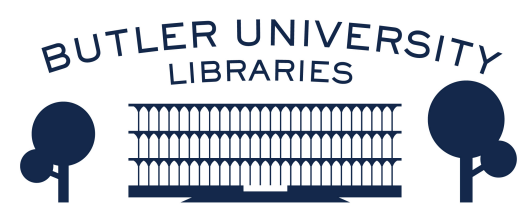

Journal of Hindu-Christian Studies

Volume 11

Article 9

January 1998

\title{
Abishiktananda: Hindu Advaitic Experience and Christian Beliefs
}

J. Glenn Friesen

Follow this and additional works at: https://digitalcommons.butler.edu/jhcs

Part of the Religion Commons

\section{Recommended Citation}

Friesen, J. Glenn (1998) "Abishiktananda: Hindu Advaitic Experience and Christian Beliefs," Journal of Hindu-Christian Studies: Vol. 11, Article 9.

Available at: https://doi.org/10.7825/2164-6279.1182

The Journal of Hindu-Christian Studies is a publication of the Society for Hindu-Christian Studies. The digital version is made available by Digital Commons @ Butler University. For questions about the Journal or the Society, please contact cbauman@butler.edu. For more information about Digital Commons @ Butler University, please contact digitalscholarship@butler.edu. 


\title{
Abishiktānanda: Hindu Advaitic Experience and Christian Beliefs
}

\author{
J. Glenn Friesen \\ University of Calgary
}

\begin{abstract}
DOM HENRI LE SAUX (Abhishiktānanda) was a Roman Catholic priest who attempted to integrate the Hindu advaitic experience of the Self with his beliefs as a Christian. ${ }^{1}$ From the time he arrived in India in 1948 to his death in 1973, there was a radical change in Abhishiktānanda's religious beliefs. This change in beliefs was as a result of his advaitic experiences. His certainty in the truth of the experiences increased over time. In an early Journal entry ${ }^{2}$ he speaks of his anguish and fear, a fear of risking his eternity for an experience that might be only a mirage. By 1972 , however, Abhishiktānanda was absolutely convinced of the truth of his experience. $\mathrm{He}$ wrote in his journal, "The experience of the Upanishads is true. I know it!"3

In his earlier writings, Abhishiktānanda referred to the complementarity of Hindu and Christian beliefs. Advaita reminds us that God can never be contained in concepts. It delivers us from our tendency to transform the mystery of the Trinity into tritheism or at the other extreme, simple modalism. ${ }^{4}$ Similarly, in Sagesse hindou mystique chrétienne, which was published in 1965 [subsequently translated in English as Saccidananda], he said that the doctrine of the Trinity helps us to avoid a monistic conception of advaita:
\end{abstract}

If the Word is God, we cannot say two (in a numerical sense) of him and the Father; there is no place left for any division, duality, dvaita of any kind. But if the Word is with God, then God is not a mere monad either. ${ }^{5}$

The Being disclosed by the advaitic experience is not monistic, but communion, koinōnia. If Being were not communion, nothing would exist, and there would be no subject, no "I" to speak about it.

At the very Source of Being, the one without a second of the Chandogya Upanishad $(6,2)$, there is koinonia, coesse, "being-with", "being together", community of being, mutual love and communication of life, an eternal call to each other, an eternal rest in each other. In its most impenetrable core of nonduality Being is threefold movement within Itself towards Itself, the triple achievement of Itself in Itself. ${ }^{6}$

Later, in 1970, Abhishiktānanda spoke not of complementarity, but of a tension between advaita and Christianity:

Will the Christian experience ... be capable of being expressed without dilution when approached from the advaitin experience? In Sagesse I attempted a meditative approach within the framework of classical theology. The last chapter shows that the problem is unresolved. The best course is still, I. think, to hold on under extreme tension to these two forms of a unique 'faith' until the dawn appears. For advaita and theology are on two levels. ${ }^{7}$

But in a letter of September 1972, Abhishiktānanda said that in writing Sagesse, he had been too much a slave to Greek concepts. ${ }^{8}$ Concepts, dogmas, and rituals are all on the phenomenal level, the level of nämarüpa (names and forms, the level of myth and logos). In February 1973, Abhishiktānanda said that the whole 
Trinitarian structure that he had set out in Sagesse had collapsed. ${ }^{9}$ At that time he was working on the English translation of Sagesse, and he said that the whole thesis in the book was "outmoded".

But it is hard to have to check the translation of a book whose thesis one no longer accepts ... Of all that I have written, Gnānannanda is almost the only thing that remains afloat. All the rest consists of nāmarüpa amusing itself with the 'theology of fulfilment'. 10

It is not only Christian concepts which are on the level of nāma-rüpa. Abhishiktannanda says that this applies as well to Śankara's monistic interpretation of reality in Vedanta; not even his formulation of advaita can be considered to be absolute. We must awaken to the pure advaitic experience revealed in the Upanishads, beyond all theology whether Vedantic or Judeo-Christian:

There is neither opposition nor incompatibility between Christianity and advaita, but rather two different levels. Advaita is not in opposition to anything; it is not a philosophy, but rather an anubhava - existential experience. All Christian thought is valid in its order, the order of manifested reality (vyavahähara) but not on the absolute level (paramärtha). Undoubtedly the Christian darshana (system, point of view) is opposed to the Vedantic darshana, but that is purely on the doctrinal level. No formulation, even that of advaita can claim to be absolute. It is another matter whether Christianity has historically gone beyond those limits. ${ }^{11}$

From his writings, it is clear that he thought that Christianity had in fact gone beyond its limits. It is even questionable whether he continued to believe that "All Christian thought is valid in ... the order of manifested reality". He seemed in fact increasingly to prefer the formulations of Vedanta to those of Christianity. Let us look at the changes in his beliefs, under several headings:

\section{God}

Abhishiktānanda's beliefs changed from seeing God as Transcendent Other to God as immanent in everything and especially in the Self. In the West, he said, we begin with a distinction between God and humanity. The awe and the fear of the sacred which we feel is projected as an "Other". ${ }^{12}$ We do not dare to accept our self as absolute. So the absolute is "reported", or projected, as God. In India, the experience of the Self is so full of the mystery of God that it is not possible to project God. ${ }^{13} \mathrm{God}$ is that depth of us which is outside of time and outside of contingency. ${ }^{14}$ And when we use the word "other" in reference to God, it must be remembered that we are using it in a very different sense than when we use it to refer to distinctions in the created world. ${ }^{15}$

Abhishiktānanda experienced a sense of loss with respect to this projected sense of God, and he compared this sense of loss with the dark night of the soul reported by Christian mystics:

The God of my projection is dead. This disappearance of God is considered as night by St. John of the Cross. I have lost God, and in searching for him, it is my self that I have found, but what a Self! ${ }^{16}$

The Self includes God, for Spirit is the interior presence of God in everything, especially in us. Because the Spirit of God is in everything, the mystery of God is expressed equally well by a "polytheistic" myth as by a "monotheistic" myth. They are all manifestations of God. ${ }^{17}$ And all these. myths point beyond themselves to God.

\section{The Uniqueness of Jesus}

Abhishiktānanda's beliefs regarding Jesus changed from seeing Jesus as the unique incarnation of God to seeing Jesus as a human like us who is a paradigm for our lives, in showing us the advaitic experience. The fundamental experience for Jesus was his baptism. Abhishiktānanda compares this 
with the experience of Ramana Maharshi, who also had the experience of being possessed by the Spirit of God. ${ }^{18}$ Baptism did not give anything to Jesus, but revealed who he was. Jesus had discovered that the "I am" of Jahweh belonged to him. 19 Abhishiktānanda says that for Jesus to call God " $A b b a$ " was the Semitic equivalent of the advaitic experience. ${ }^{20}$ This is a revelation which belongs to everyone. ${ }^{21}$ Every person may become a "son" or child of God. When we become sons of God, we pass from non-Being to Being. 22

As a paradigm for us, Jesus is not unique. Jesus was not the only epiphany of God. So was the Buddha, and so was Ramana Maharshi. But if Jesus is not a unique paradigm, what is the significance of Jesus in history? It is not its historicity that gives Christianity its value, but the intemporal values expressed in it. ${ }^{23}$. What are these values? Only the attitude of Jesus during his life has universal validity: the sermon on the mount, the commissioning of the disciples, his freedom, ${ }^{24}$ and his teaching of dispossession-insecurity. ${ }^{25}$

Initially, Abhishiktānanda tried to preserve the uniqueness of Jesus by saying that it is only as we "participate" in Him that we become sons of God. We are "sons in the Son". 26

Jesus, as the perfect son of Man, satpurusa, was the first to receive this [full revelation of glory], and did so in the name of all men. No one can ever reach it, unless he participates in the unique experience of Jesus. ${ }^{27}$

But by 1972 Abhishiktānanda had concluded that the problem of the uniqueness of Christ is a false problem, one which arises only in the context of phenomena. ${ }^{28}$ Jesus is as unique as is every consciousness. All are incomparable. Whoever awakens to the mystery of Brahman under the name of the Father is the only Son. ${ }^{29}$

God is unique for Jesus, and God is unique for me. Jesus is the only begotten (monogenes), and I am the only begotten. For the Father, everyone is as unique as is Jesus. The distinction between Jesus and other persons is the same distinction as between each person with respect to others. ${ }^{30}$

"Uniqueness" then means only that Jesus was an individual within the manifested reality of this world. As one such individual, he showed us how to recognize our divine sonship and oneness with God.

All that the Christ said or thought about himself, is true of every man. It is the theologians who - to escape being burnt, the devouring fire - have projected (rejected) into a divine loka. [sphere] the true mystery of the Self. ${ }^{31}$

The projection of the experience into the divine sphere occurs even in the Biblical record of Jesus' experience:

To save itself from this depth experience which annihilates everything of which the human ego knows of itself, Biblical thought (New Testament) has rejected in the divine sphere ... this identity with Brahman which it had discovered - for without an identity in this sense, how could the identity of Jesus as human and as God be even thought? Biblical thought has as well projected into this same divine sphere the I-THOU of his relation with God equally to save it - leaving to theologians the job of saving the mystery by their abstractions while lay persons try to cope with these approximations which falsify the sense of the revelation itself. ${ }^{32}$

Salvation is shown by Jesus, but it is not dependent on any particular acts in history involving Jesus. The Christian doctrine of atonement through the death of Christ can no longer be maintained. It is a juridical view that is based on a dualism, where God and humans are two partners, the latter of which has sinned against the former. ${ }^{33}$ But salvation takes place in the human heart, at the centre of our being, where such a notion of partnership is impossible:

And here [in the heart] it is absolutely 
impossible to regard God as a partner, and still less to regard oneself as a partner of God. Even the most intense humility of the repentant sinner is surpassed, because in order for humility and repentance to exist, one must of necessity project at least oneself before God. The depth experience (of being) does not permit this; all is burned away; the sinner doesn't even find place to recognize himself or herself as a sinner. One is uncovered in one's being, as a being, and in this ex-istence one has left everything that so to speak constituted oneself. ${ }^{34}$

Abhishiktānanda says that salvation is not to be found in the realm of namarūpa, whether death, sacrifice, redemption, or resurrection. There is only one act by which Jesus - and anyone - passes to the Father: It is the act of awakening to the Presence of God. ${ }^{35}$ This "I am", this awakening to one's Self, is also the awakening of God to Himself. ${ }^{36}$ Rites, formulas, myths all have only symbolic value, in pointing to this act of awakening. But we must obstinately oppose giving absolute value to these rites, formulas, and myths, or finding our salvation in terms of anything in the realm of nāmarüpa. Jesus opposed the absolute value given to them in his day; his claim of freedom to be himself led to the cross. ${ }^{37}$

\section{The Trinity}

Already in Saccidānanda, Abhishiktānanda expressed doubts as to whether the belief in the Trinity is necessary:

Within this blinding intuition of Being, how can the Christian be sure that what he believes he has discovered about himself and the world in God through the biblical revelation of the Trinity is true? It seems rather that all this is merely a last-minute attempt to salvage what he cannot bear to abandon when he comes to make the final plunge into the abyss that attracts him so powerfully. ${ }^{38}$

In his earlier writings, Abhishiktānanda distinguished between cosmic revelation given in creation, and special, or biblical revelation. Hinduism belongs to cosmic revelation, which is the religious experience of all those outside of the biblical tradition. ${ }^{39}$ The Christian has been given special revelation of doctrines such as the Trinity.

For the Christian the Bible must always be the point of departure and the point of return; it is not a mere reference book, to be consulted now and then simply to illuminate or confirm the discoveries of reason or spiritual experience. ${ }^{40}$

And yet in his later writings, Abhishiktānanda does precisely this: he uses the Bible to illuminate the spiritual experience. The experience is primary, and is known from the revelation in creation. There is no revelation, whether cosmic or biblical, apart from what is given in creation in being. Revelation is not something that occurs after creation. ${ }^{41} \mathrm{He}$ says that any theological discussion of the Trinity must commence not with definitions or creeds or even statements from the New Testament, but rather with the experience that Jesus, as a human, had of God. ${ }^{42}$ His experience of divine sonship is the same as the advaitic experience of tat tvam asi... If we begin with creeds and definitions of the Trinity, it becomes the most abstract thing we can think of, with no influence on our lives, whereas for Jesus this was his most concrete experience. ${ }^{43}$

The doctrine of the Trinity is in the phenomenal realm of nammarüpa. Neither the term "Trinity" nor the theology concerning it has been revealed in the New Testament. It is a reflection of faith within a Greek framework. $^{44}$ In a letter dated 23 December 1970, Abhishiktānanda said he should have to start all over again, beginning with the Vedantin experience, instead of with his Christian beliefs.

I thought I had said much more in my letter than you seem to have taken in, I mean, my feeling that I am incapable of going beyond the thoughts already 
expressed (in books and letters) without Christianity exploding ... The whole subject should be taken up again, starting from the Vedantin experience, and not - as I have so far done, or rather written - starting from the "Christian faith" and its "symbolization" [in Creeds] by the [Ecumenical] Councils; like a kind of hypothesis which is followed through to the end ... What are we to do? In the blinding light which blots out every outline, what place remains for a "symbolic" [creed] of any kind whatever? ${ }^{45}$

The idea of the Trinity arises from our existential experience of Being itself. The Trinity is the projection in God of the reciprocity of being (parasparam) ${ }^{46}$

Rightly understood, the experience of the Trinity is the experience of my relation with each of my fellow-men and with every creature. ${ }^{47}$

The experience of the Trinity is that of finding ourselves as individuals in the manifested world, and then relating this experience to the Source of our being, which is the unmanifested reality. The Son, or the manifested, proceeds from the unmanifested. And this divine sonship is also ours. And Spirit is the force, energy or shakti, which is another manifestation of the unmanifest. We do not have experience or true knowledge of the Trinity except in the mystery of our being. ${ }^{48}$ But the doctrine of the Trinity is just one culturally conditioned expression for this experience of this relation between unmanifested being and manifested being.

By 1973 Abhishiktānanda explicitly rejected the possibility of the development of a new Trinitarian theology - that would be to remain enchanted in the world of myths and logos. It would be replacing Theos by theo-logia. The awakening to the mystery has nothing to do with the dogmas of the Trinity, Incarnation, Redemption, or finding equivalences to the mystery of Jesus in Indian terms like avatars or Purusha. ${ }^{49}$

\section{The Superiority of Advaita}

If all theologies are on the phenomenal plane, on the level of nämarüpa, how do we choose between them? Abhishiktānanda says we should stay with the tradition we were brought up with. ${ }^{50} \mathrm{He}$ said he continued to have a "visceral" attachment to Christian doctrines and concepts. ${ }^{51}$ It was in Christ Jesus that he discovered the mystery in himself, and it was in the image and symbol of Christ Jesus that he came to know God. Since his awakening, this symbol has been "marvellously amplified". But Abhishiktānanda recognized the same mystery in Shiva, Purusha, Krishna, Rāma and others. ${ }^{52}$

And yet Abhishiktānanda himself did not stay within the Christian forms of thinking. There are many passages in his writings which indicate that he viewed the Vedantic way as superior. He says that the spirituality of the East surpasses both Judaism and Christianity, and that Vedantic experience can purify Christian ideas:

Before seeking to impose in Hindus their own ideas of God, sin and redemption, Christians should first of all allow these to be refined and purified in the pitiless light which is thrown by the Vedantic experience on every attempt to conceptualize the divine Mystery. ${ }^{53}$

Christianity is only a "view" of the advaitic mystery. ${ }^{54}$ In the Indian form of the message there is a universality which no Jewish or Greek thought can equal. ${ }^{55}$ When it became a religion, Christianity lost its mystery and its force. ${ }^{56}$ Christian institutions and formulations only find their true value when read in the framework of the experience of atman-brahman, and not through that of Greek philosophy or Hebrew metaphysics.

The Jews have reduced Jesus Ben Adam [the Son of Man] to the Messiah of their history of salvation; the Greeks have made of him a divine descent, the descent to earth of their Logos. India, free of history and especially of historic 
particularity - this impossible "People of God" - is also free of logos and of eidos, and grasped immediately the universal mystery, the Purusha which, outside of all history and all eidos, appeared agre: at the origin of everything, at the origin of the whole cosmos, at the origin of human consciousness as well. ${ }^{.7}$

The Hindu myth of Purusha is "more extensive" than that of Christ. Unlike the myth of Christ, it is not attached to time. It acknowledges all the symbolic value contained in the mystery of time, but refuses to condense the Absolute to one particular point in time. ${ }^{58}$

These changes in Abhishiktānanda's beliefs are surprising, especially considering that he remained a Roman Catholic priest until his death. It has been argued that we should not place too much weight on his journal entries or his posthumously published works, since they were not intended for publication or at least not ready for publication, or that Abhishiktānanda was not really a theologian, and therefore did not really intend what he said. ${ }^{59}$ But why should we suppose that Abhishiktānanda's views as expressed in his journals are more provisional than the works published in his lifetime? In fact, these journals seem to express his real views. We know that by 1973 he no longer accepted most of what he had published. And he also had not been permitted to publish many of his ideas. Guhāntara, the first book he proposed to publish under his own name, was severely criticized in 1954 by the Paris censor, who found heresies on every page. ${ }^{60}$ Abhishiktānanda tried again to publish it in 1956, and again it received heavy criticism. Guhāntara was written in 1953-54 but was never published in Abhishiktānanda's lifetime, even though he considered it his most creative work. (Some of it was published posthumously in Intériorité et Révélation.) His book on his experiences up to 1956 with Śri Gnānānanda Giri of Tirukoyilūr was not published until 1970; even then, Abhishiktānanda referred to himself in the third person as the disciple "Vanya". ${ }^{61}$ In his journals, he did not have to be as cautious in revealing the change in his beliefs.

\section{Conclusion}

Abhishiktānanda's advaitic experience had a profound change on his beliefs as a Christian. He initially tried to interpret the advaitic experience in Christian terms. But he ended by accepting the authenticity of the experience and trying instead to reconcile and to interpret his previous Christian beliefs in relation to that experience. ${ }^{62}$ What was primary for Abhishiktānanda was his advaitic experience, and that experience resulted in a change in his beliefs.

\section{Notes}

1. The advaitic experience is that the Self and Brahman are "not two". As interpreted by Abhishiktānanda, this advaitic experience need not necessarily be understood in a monistic sense as in Śankara's system.

2. La montée au fond du cour: Le journal intime du moine chrétien-sannyasi hindou. 1948-1973 (O.E.I.L., Paris, 1986) (Journal entry, 27 November 1956), p. 222. This book is a selection by R. Pannikar from Abhishiktānanda's journal, published to date only in French. The translations in this paper are my own.

3. La montée au fond du cœur, (Journal entry, May 1972), p. 425.

4. La rencontre de l'hindouisme et du christianisme (Paris: Le Seuil, 1966), translated in English as Hindu-Christian Meeting Point (Delhi: ISPCK, 1976)

5. Saccidananda, (Delhi: ISPCK, 1974), p. 84.

6. Saccidananda, p. 109

7. Stuart, James: Swami Abhishiktananda: His life told through his letters (Delhi: SPCK, 1989), Letter dated 5 December 1970, p. 268.

8. Cited by Dupuis, introduction to Intériorité et Révélation: Essais théologiques (Henri Vaud, France, 1982), p. 22. This book is a collection of essays which was published after Abhishiktānanda's death. The 
translations in this paper are my own.

9. La montée au fond du cour (Journal entry, Feb. 1973), p. 450.

10. Stuart, James: Swami Abhishiktananda: His life told through his letters (Delhi: SPCK, 1989), Letter dated 2 April 1973 to his disciple Marc Chaduc, p. 321.

11. La montée au fond du cour, (Journal entry, Oct. 1970), p. 393.

12. "Theologoumenon upasana: méditation sur la Trinité" (1970), Intériorité et Révélation, p. 230

13. Letter 2.9.72, cited by Dupuis, Intériorité et Révélation, p. 20.

14. La montée au fond du cour, (Journal entry, January 1967), p. 354.

15. "Cheminements Intérieurs", Intériorité et Révélation, p. 45, footnote 13. And p. 92: "Car Dieu est tout autre qu'un autre."

16. La montée au fond du caur, (Journal entry, April 1973), pp. 461, 462

17. La montée au fond du caur (Journal entry, Sept. 1967) , p. 359

18. La montée au fond du cour, (Journal entry, October 1966), p. 345 and see also "Sannyasa", The Further Shore, (ISPCK, Delhi, 1975), p. 52.

19. "Theologoumenon upasana: méditation sur la Trinité" (1970), Intériorité et Révélation, p. 226 , where John $8: 58$ is cited: "Before Abraham existed, I am."

20. Letter dated 16.1 .73 , cited by Dupuis, introduction to Intériorité et Révélation, p. 24.

21. La montée au fond du cœur, (Journal entry, October 1966), p. 346

22. Hindu-Christian Meeting Point, (ISPCK, Delhi, 1976), p. 91.

23. La montée au fond du cœur, (Journal entry, October 1972), p. 438.

24. "Sat-Purusha" (1973), Intériorité et Révélation, p. 300

25. La montée au fond du cour, (Journal entry, May 1967), p. 357. Abhishiktānanda takes many Biblical passages literally: "Go sell what you have", "Take nothing for your journey - no staff, bag, bread, money, no change of clothes", "Sannyasa", The Further Shore, p. 50.

26. Hindu-Christian Meeting Point, p. 118.

27. Saccidananda: $A$ Christian approach to advaitic experience, (ISPCK, Delhi, 1974), p. 84

28. La montée au fond du cœur, (Journal entry,
December 1972), p. 442

29: "Sat-Purusha" (1973), Intériorité et Révélation, p. 299

30. La montée au fond du cour, (Journal entry, Dec. 1971), p. 409

31. Stuart, James: Swami Abhishiktananda: His life told through his letters (Letter, 2 April 1973), p.322.

32. "Theologoumenon upasana: méditation sur la Trinité" (1970), Intériorité et Révélation, p. 220

33. "Jésus le sauveur” (1971), Intériorité et Révélation, p. 275

34. "Jésus le sauveur" (1971), Intériorité et Révélation, p. 279

35. "Jésus le Sauveur" (1971), Intériorité et Révélation, p. 279

36. "In principio erat verbum" (1971) Intériorité et Révélation, p. 307

37. La montée au fond du cour, (Journal entry, Feb. 1973), p. 450 and Stuart, James: Swami Abhishiktananda: His life told through his letters (Letter, 2 April 1973), p.322.

38. Saccidananda, p. 195

39. Saccidananda, p. 52

40. Hindu-Christian Meeting Point, p. 83

41. "Révélation cosmique et révélation dans le Christ” (1970), Intériorité et Révélation, p. 253

42. "Notes de théologie trinitaire" Intériorité et Révélation.

43. "Notes de théologie trinitaire" (1973), Intériorité et Révélation, p. 243

44. "Theologoumenon upasana: méditation sur la Trinité" (1970), Intériorité et Révélation, p. 229

45. Stuart, James: Swami Abhishiktananda: His life told through his letters (Delhi: SPCK, 1989), Letter dated 23 December 1970, p. 270.

46. "In principio erat verbum" Intériorité et Révélation, p. 310.

(1971),

47. "Approach to the Upanishads", The Further Shore, p. 77

48. "Theologoumenon upasana: méditation sur la Trinité” (1970), Intériorité et Révélation, p. 231

49. La montée au fond du cour, (Journal entry, Feb., 73), p. 450.

50. "Sannyasa", The Further Shore, p. 43.

"As long as we remain at the level of signs, the best signs for us are normally those 
among which we first awoke as men, and as men devoted to God, even if later on those signs have to be purified and freed from their limitations and particularity."

51. La montée au fond du cour, (Journal entry, Sept. 1970), p. 390

52. La montée au fond du cour, (Journal entry, Aug. 1971). Thus, Dupuis is incorrect when he states that Abhishiktānanda did not hesitate to recognize the superiority of Christianity on the phenomenal level. (Introduction to Intériorité et Révélation, $\mathrm{p}$. 22).

53. Hindu-Christian Meeting Point, p. 115

54. La montée au fond du cour, (Journal entry, April 1956), p. 188.

55. La montée au fond du cour, (Journal entry, July 1971) , p. 403

56. La montée au fond du cour, (Journal entry, Jan. 1973), p. 447

57. La montée au fond du cour, (Journal entry, Dec. 1972) , p. 442.

58. "Sat-Purusha" (1973), Intériorité et Révélation, p. 304; also La montée au fond $d u$ cceur (Journal entry, Feb. 1973), p. 453; also "Approach to the Upanishads", The Further Shore, p. 100.
59. Dupuis, J., Introduction to Intériorité et Révélation, p.28. Dupuis questions whether the advaitic experience can truly be compared with Christian mysticism, and whether it properly describes the experience of Jesus at his baptism. Dupuis is especially concerned at the radical relativity given by the advaitic experience to history. And yet Dupuis acknowledges that Abhishiktānanda did have a good knowledge of theology; he had participated in theological conferences. He was aware of changes in Roman Catholic theology since the Vatican Council, and he was current in his knowledge of Western debates concerning Christology.

60. Stuart, James: Swami Abhishiktananda: His life told through his letters (Delhi: SPCK, 1989), p.83.

61. Gnanananda, un maître spirituel du pays tamoul (Ed. Presence, 1970); English translation Guru and Disciple (S.P.C.K., 1974)

62. According to R. Panikkar, Abhishiktānanda arrived in India to testify about Christ, but ended by being converted by those he had wanted to convert. (Preface to La montée au fond du cour, p. V). 